О.І. Бублієва, В.С. Свінціцький, С.В. Неспрядько, Н.П. Ціп, В.І. Копецький, М.С. Кротевич, Н.А. Леонова, О.М. Мовчан

\title{
Оцінка лімфатичних вузлів у лікуванні раку тіла матки. Стан проблеми
}

\author{
Національний інститут раку, Київ \\ Одержано 27.09.2021 \\ Прийнято до друку 19.11.2021 \\ DOI: 10.32471/clinicaloncology.2663-466X.43-3.28292
}

Рак ендометрія займає третє місце у структурі захворюваності на злоякісні пухлини в Україні (9,6\%). Тазова та парааортальна лімфодисекція $є$ методами оцінки лімфатичних вузлів. Тим не менш, опубліковані раніше результати досліджень показали, що названі вище хірургічні втручання не впливають на загальну виживаність. Логічною альтернативою може стати біопсія сигнального лімфатичного вузла з використанням індоціаніну зеленого. Наше проспективне рандомізоване нонінферіоріті дослідження $є$ мультицентровим і має за мету порівняти безрецидивну виживаність у жінок із ендометріоїдним раком проміжної та високопроміжної груп ризику.

Ключові слова: рак тіла матки; лімфодисекція; сигнальний лімфатичний вузол; індоціанін зелений.

\section{ВСТУП}

Рак ендометрія (РЕ) - найбільш розповсюджене онкогінекологічне захворювання серед жінок, що, за даними Національного канцер-реєстру, займає третє місце у структурі захворюваності на рак населення України у 2020 р., а у структурі смертності серед усіх нозологічних форм злоякісних новоутворень (3Н) - дев'яте місце [1] (рис. 1).

Станом на 2019 р., за даними Національного канцерреєстру, серед жінок віком 30-54 роки питома вага у структурі захворюваності на 3Н тіла матки становить 9,0\%, займаючи третє місце, як і серед жінок віком 55-74 роки $11,7 \%$, аналогічне місце. У порівнянні з 2018 р. у віковій структурі 30-54 роки такий показник становив 8,7\%, а в групі 55-74 роки $-12,1 \%$. Станом на 2020 р. на обліку перебуває 82481 пацієнтка із злоякісним новоутворенням тіла матки. Загальна кількість випадків у 2019 р. склала 6857, а кількість померлих - 1544. 9,8\% хворих не прожили одного року з числа пацієнтів з уперше виявленою патологією станом на 2019 р. Найбільшу кількість випадків захворювання на ЗН тіла матки у 2020 р. було зареєстровано у Дніпропетровській обл. (541), м. Київ (522), Львівській обл. (431), Харківській обл. (388). У 68,5\% пацієнтів було виявлено I стадію захворювання, у $10 \%$ - II, у 8,7\% - III та у $4,2 \%$ - IV.

У Європі, за даними бази GLOBOCAN, Україна посідає п'яте місце у структурі смертності від злоякісного захворювання тіла матки станом на 2020 р., саме тому питання оптимізації лікування є досі актуальним [2] (рис. 2).

\section{МЕТА РОБОТИ}

Провести аналіз основних клінічних досліджень, які було проведено з метою оцінки впливу лімфодисекції на віддалені онкологічні результати, а також впливу біопсії сигнального лімфатичного вузла у пацієнток з РЕ I стадії. Також у роботі вказано основні положення розпочатого проспективного рандомізованого дослідження хворих на РЕ проміжного та високопроміжного ризику.

\begin{tabular}{|c|c|c|c|}
\hline Молочна залоза & 20.3 & Молочна залоза & 20.1 \\
\hline Немеланомні 3Н шкіри & 12.9 & Ободова кишка & 8.4 \\
\hline Тіло матки & 9.5 & Шлунок & 7.5 \\
\hline Ободова кишка & 6.6 & Трахея, бронх, легеня & 6.6 \\
\hline Шийка матки & 5.4 & Пряма кишка & 6.4 \\
\hline Яєчник & 4.9 & Яєчник & 6.4 \\
\hline Пряма кишка & 4.8 & Шийка матки & 5.9 \\
\hline Шлунок & 4.2 & Підшлункова залоза & 5.8 \\
\hline Щитоподібна залоза & 3.7 & Тіло матки & 5.7 \\
\hline Трахея, бронх, легеня & 3.6 & $\begin{array}{r}\text { Неуточнена первинна } \\
\text { локалізація }\end{array}$ & 2.9 \\
\hline (a) Iншi & 24.1 & (6) Інші & 24.3 \\
\hline
\end{tabular}




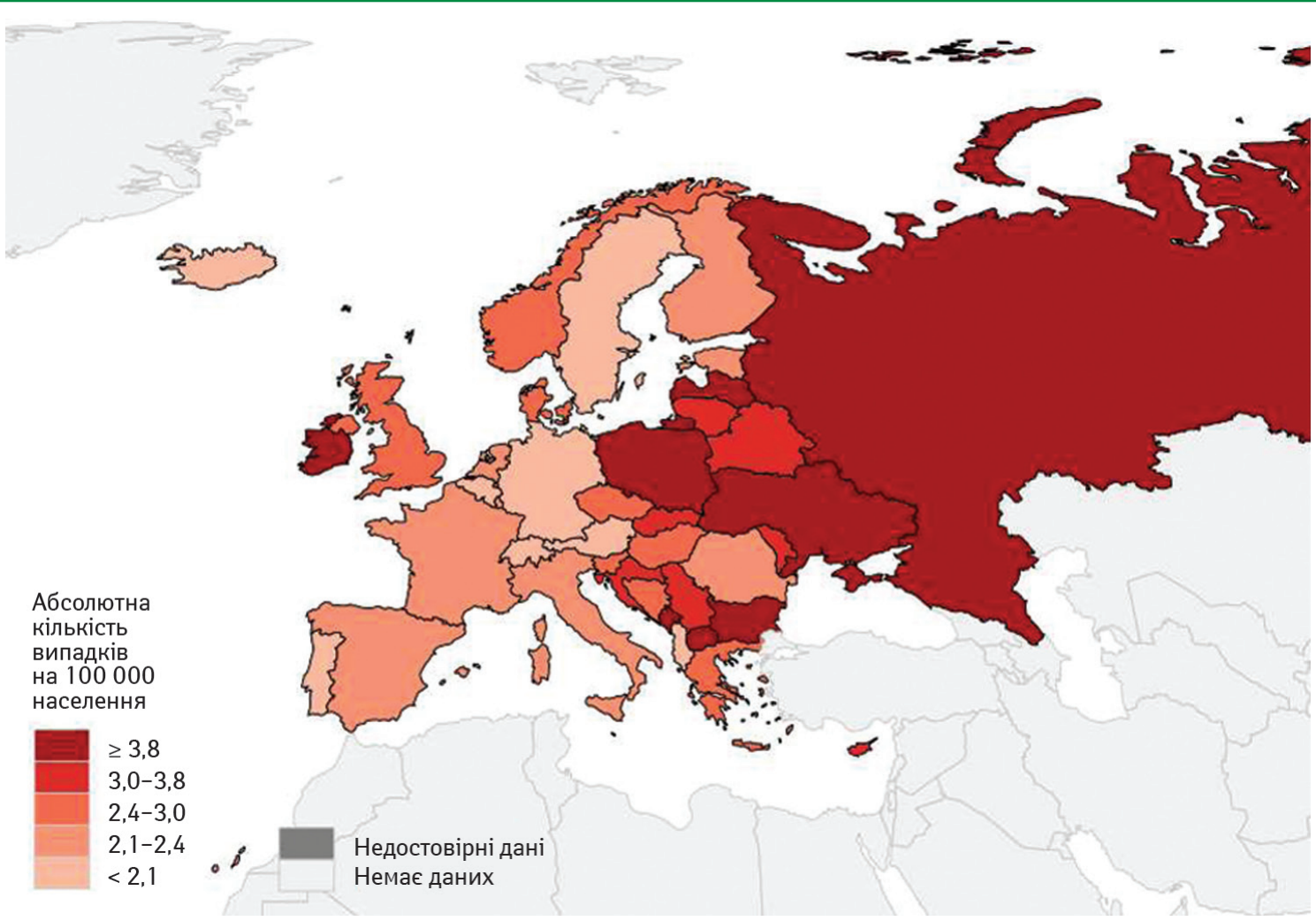

Рис. 2. Стандартизований показник смертності у 2020 р., ЗН тіла матки

\section{ОБ'ЄКТ ТА МЕТОДИ}

У Національному інституті раку розпочато проспективне рандомізоване контрольоване дослідження, що має на меті проаналізувати безрецидивну виживаність у пацієнток із ендометріоїдним РЕ I стадії проміжного та високопроміжного ризику, яким було виконано біопсію сторожового лімфатичного вузла (СЛВ) (І група) та системну лімфодисекцію (II група); порівняти післяопераційні ускладнення та якість життя пацієнток у контрольній та досліджуваній групах (рис. 3).

Критерії включення наступні: РЕ I стадії за даними інструментальної діагностики, низько- та високодиференційована карцинома з інвазією в міометрій більше $50 \%$, низькодиференційована карцинома з інвазією менше половини міометрію. Критеріями виключення є пацієнтки низької групи ризику та іншої гістологічної форми, окрім ендометріоїдної, а також II, III, IV стадії (рис. 4).

Патоморфологічна оцінка буде здійснюватися згідно з адаптованим протоколом College of American pathologists,
Version Endometrium 4.1.0.0, August 2018, включаючи класифікацію рTNM, $8^{\text {th }}$ edition, стадіювання Міжнародної федерації акушерів та гінекологів (International Federation of Gynecology and Obstetrics - FIGO) згідно з Staging Manual Об'єднаного американського комітету з раку (American Joint Committee on Cancer - AJCC), 2015 Cancer Report, затвердженим етичним комітетом Національного інституту раку.

Ізольовані пухлинні клітини сигнальних лімфатичних вузлів, виявлені шляхом імуногістохімічного дослідження, будуть позначатись як «No(i+)».Ця група пацієнток буде підлягати окремому протоколу спостереження, вказаному нижче.

Пацієнток будуть спостерігати з наступними інтервалами: через 30 днів (оцінка післяопераційних ускладнень за Clavien - Dindo), потім кожних 4 міс впродовж двох років із заповненням опитувальників EORTC QLQ-C30 та LYMQOL для оцінки якості життя.

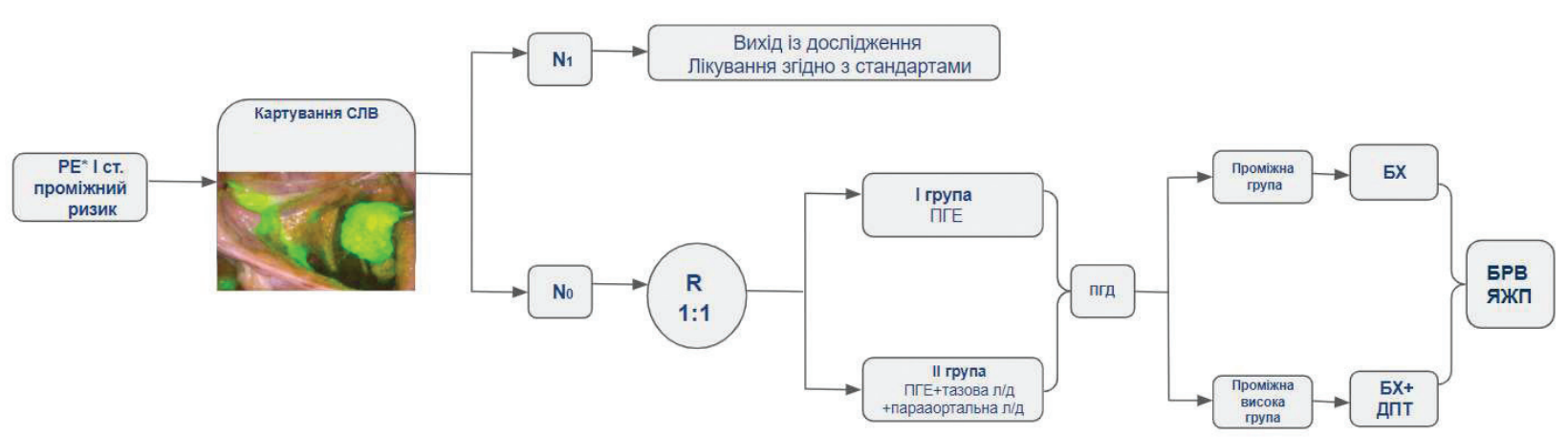

Рис. 3. Дизайн дослідження 


\section{ОБГОВОРЕННЯ}

Системна лімфодисекція. Тактика хірургічного лікування, як і подальшого ад'ювантного, базується на групах ризику метастазування - низького, проміжного, високопроміжного та високого [3]. Довгий час триває дискусія на тему хірургічного лікування РЕ І стадії, а саме доцільності виконання лімфодисекції.

Дослідження GOG33 показало кореляцію ступеня інвазії і гістологічного варіанту з ймовірністю розповсюдження в лімфатичні вузли у пацієнток з І стадією. У $11 \%$ хворих були виявлені метастази в лімфатичних вузлах (в тазових і/або в парааортальних). Тільки у $3 \%$ відзначали метастази як у тазових, так і в парааортальних, у $2 \%$ пацієнток визначали метастази тільки в парааортальних лімфатичних вузлах. У $6 \%$ - позитивні тазові лімфатичні вузли за негативних парааортальних. Достовірної різниці між гістологічним типом пухлини та метастазами в лімфатичні вузли дослідження не показало, на противагу глибині інвазії. У пацієнток з глибокою інвазією в міометрій ймовірність метастазування найвища: в тазові лімфатичні вузли при низькодиференційованій аденокарциномі - 34\%, при високодиференційованій пухлині $-11 \%$, а в парааортальні - 23 і 6\% відповідно до вищезазначеної диференціації [4].

На сьогодні є два рандомізованих проспективних дослідження, де було проаналізовано загальну виживаність пацієнток з раком тіла матки відповідно до обсягу хірургічного втручання.

Перше 3 них - дослідження ASTEC, вибірка якого склала 1408 пацієнток. За результатами цього дослідження загальна та безрецидивна виживаність у групі тотальної гістеректомії та групі, де було виконано лімфодисекцію, не відрізнялись. Але варто зауважити, що рівень виконаної лімфодисекції обмежувався тазом, середня кількість видалених лімфатичних вузлів - дев'ять. Окрім того, не було систематизовано ад’ювантне лікування. Більша кількість пацієнток отримали лише дистанційну терапію («Efficacy of Systematic Pelvic Lymphadenectomy in Endometrial Cancer (MRC ASTEC Trial): A Randomised Study», 2009) [5].

Інше італійське рандомізоване дослідження Р.B. Panici, до якого було залучено 31 центр з вибіркою в 514 пацієнток, також не показало достовірної різниці в загальній виживаності. Хоча тут середня кількість становила 30 видалених лімфатичних вузлів, а у $26 \%$ була представлена парааортальна лімфодисекція. Але, як і в першому дослідженні, вибір ад’ювантного лікування здійснювався на розсуд центру [6].

SEPAL, японське ретроспективне дослідження, peзультати якого було оприлюднено у 2010 р., показало, що загальна виживаність пацієнток проміжної та високої групи ризику в групі виконаної парааортальної та тазової лімфодисекції вища, ніж у групі лише тазової. Звертає на себе увагу те, що 77\% пацієнток у групі парааортальної та тазової лімфодисекції отримали хіміотерапію, що суттєво відрізняється від групи контролю $-45 \%$, тому виникає питання, що саме вплинуло на такі віддалені результати - вибір ад'ювантного лікування чи обсяг хірургічного втручання [7].

Питання розширення обсягу хірургічного лікування є досить актуальним, зважаючи на всі ризики післяопераційних ускладнень, пов'язаних із цим.

N. Abu-Rustum у своєму ретроспективному дослідженні проаналізував дані 1289 пацієнток із РЕ, яким було проведено хірургічне лікування. 3 трьохрічною медіаною спостереження було виявлено лімфадему нижніх кінцівок у 16 пацієнток. У середньому симптоми лімфадеми з'являлися через 5,3 міс після операції (1-32 міс). В 11 пацієнток була уражена одна нога, в 5 пацієнток - дві [8].
Біопсія сигнального лімфатичного вузла. У 2020 р. було опубліковано результати аналізу 378 пацієнток, яким проведено біопсію сигнального лімфатичного вузла $(127 / 33,5 \%)$ та білатеральну лімфодисекцію $(251 / 66,4 \%)$. Лімфадему нижніх кінцівок відмічали в 41,5\% (157/378) пацієнток після в середньому 54 міс після операції (31,2-70,1 міс). Із них 69 пацієнток звернулися самостійно зі скаргами, а у 88 пацієнток діагноз було встановлено за опитувальником. Кількість лімфадем була більшою в групі лімфодисекції, ніж у групі біопсії сигнального лімфатичного вузла - 39\% (41/105) і 26\% (33/127 відповідно) [9].

Таким чином біопсія сигнального лімфатичного вузла зменшує не тільки кількість післяопераційних лімфадем, а і час хірургічного втручання, кількість ліжкоднів, кількість крововтрати.

На сьогодні з метою картування лімфатичного вузла рекомендують використання індоціаніну зеленого, який із 2020 р. офіційно дозволений на території України.

У рандомізованому міжнародному мультицентровому дослідженні, в якому порівняли використання індоціаніну зеленого з ізосульфаном синім у детекції СЛВ, індоціанін зелений показав високий рівень детекції - $96 \%$ у порівнянні з 74\% рівнем виявлення СЛВ з використанням ізосульфану синього. Двобічне картування відбулося в 80 та $31 \%$ відповідно [10].

Ще одне рандомізоване дослідження FIRES показало високу діагностичну чутливість препарату. Негативне прогностичне значення становило $0,4 \%$ (1/258). Важливо, що серед гістологічних варіантів, окрім ендометріоїдного раку (82\%), були наявні і серозний (12\%), і світлоклітинний (2\%), і карциносаркома (4\%) [11].

Ще одне проспективне рандомізоване дослідження SENTOR, у якому взяло участь три канадських центри показало, що у пацієнток із раком тіла матки I стадії проміжної (ендометріоїдний G1) або високої (ендометріоїдний $\mathrm{G} 3$, серозний, світлоклітинний, недиференційований) груп ризику можливе виконання біопсії сигнального лімфатичного вузла, так як хибнонегативна прогностична цінність становила $0,8 \%(1 / 258)$ [12].

У дослідженні B.A. Schlappe ретроспективно порівняно онкологічні наслідки у пацієнток з ендометріоїдним РЕ, за результатами виконання картування сигнального лімфатичного вузла відповідно до алгоритму із хворими, яким було виконано тазову та парааортальну лімфодисекцію. У результаті було виявлено, що немає зв'язку між методом оцінки лімфатичного вузла та загальною виживаністю у пацієнток з негативними лімфатичними вузлами [13].

Як показують названі вище дослідження біопсія сигнальних лімфатичних вузлів є можливою опцією в оцінці лімфатичних вузлів при РЕ І стадіі.

\section{висновок}

Таким чином, розпочате проспективне дослідження дозволить оцінити онкологічну безпеку використання індоціаніну зеленого в менеджменті жінок із ендометріоїдним РЕ І стадії проміжної та високопроміжної груп ризику, а також показати вплив тотальної лімфодисекції на якість життя пацієнток, оцінивши кількість лімфадем, які виникли в післяопераційний період і кількість післяопераційних ускладнень.

\section{КОНФЛІКТ ІНТЕРЕСІВ}

Автори заявляють про відсутність конфлікту інтересів.

\section{СПИСОК ВИКОРИСТАНОЇ ЛІТЕРАТУРИ}

1. Федоренко, З. П., Гулак, Л. О., Михайлович, Ю. Й., Горох, Є. Л., Рижов, А. Ю., Сумкіна, О. В., \& Куценко, Л. Б. (2020). Рак в Україні, 2018-2019. Захворюваність, смертність, показники діяльності онкологічної служби. О. О. Колеснік (Ред.), Бюлетень Національного канцер-реєстру України, 21, 101. 


\section{Оглядові статті / Review Articles}

2. GLOBOCAN. (2021). Estimated age-standardized incidence rates (World) in 2020, prostate, males, all ages. International Agency for Research on Cancer 2021. Retrieved from: http://gco.iarc.fr/today.

3. Concin, N., Matias-Guiu, X., Vergote, I., Cibula, D., Mirza, M. R., Marnitz, S.,... Creutzberg, C. L. (2021). ESGO/ESTRO/ESP guidelines for the management of patients with endometrial carcinoma. In International Journal of Gynecological Cancer, 31(1),12-39. doi.org/10.1136/ijgc-2020-002230.

4. Creasman, W. T., Morrow, C. P., Bundy, B. N., Homesley, H. D., Graham, J. E., \& Heller, P. B. (1987). Surgical Pathologic Spread Patterns of Endometrial Cancer. Cancer, 60, 2035-2041. Retrieved from: http://incan-mexico. org/wp_ginecologia/wp-content/uploads/GOG-33.pdf

5. Efficacy of systematic pelvic lymphadenectomy in endometrial cancer (MRC ASTEC trial): a randomised study. (2009). The Lancet, 373(9658), 125-136. doi.org/10.1016/S0140-6736(08)61766-3.

6. Panici, P. B., Basile, S., Maneschi, F., Lissoni, A. A., Signorelli, M., Scambia, G., ... Mangioni, C. (2008). Systematic pelvic lymphadenectomy vs no lymphadenectomy in early-stage endometrial carcinoma: Randomized clinical trial. Journal of the National Cancer Institute, 100(23), 1707-1716. doi.org/10.1093/jnci/djn397.

7. Todo, Y., Kato, H., Kaneuchi, M., Watari, H., Takeda, M., \& Sakuragi, N (2010). Survival effect of para-aortic lymphadenectomy in endometrial cancer (SEPAL study): a retrospective cohort analysis. The Lancet, 375(9721), 1165-1172. doi.org/10.1016/S0140-6736(09)62002-X.

8. Abu-Rustum, N. R., Alektiar, K., lasonos, A., Lev, G., Sonoda, Y., Aghajanian, C., Chi, D. S., \& Barakat, R. R. (2006). The incidence of symptomatic lower-extremity lymphedema following treatment of uterine corpus malignancies: A 12-year experience at Memorial Sloan-Kettering Cancer Center. Gynecologic Oncology, 103(2), 714-718. doi.org/10.1016/j.ygyno.2006.03.055.

9. Glaser, G., Dinoi, G., Multinu, F., Yost, K., Al Hilli, M., Larish, A., ... Mariani, A. (2021). Reduced lymphedema after sentinel lymph node biopsy versus lymphadenectomy for endometrial cancer. International Journal of Gynecological Cancer 31(1), 85-91. doi.org/10.1136/ijgc-2020-001924.

10. Frumovitz, M., Plante, M., Lee, P. S., Sandadi, S., Lilja, J. F., Escobar, P. F., ... Abu-Rustum, N. R. (2018). Near-infrared fluorescence for detection of sentinel lymph nodes in women with cervical and uterine cancers (FILM): a randomised phase 3, multicentre, non-inferiority trial. The Lancet Oncology, 19(10), 1394-1403. doi.org/10.1016/S1470-2045(18)30448-0.

11. Rossi, E. C., Kowalski, L. D., Scalici, J., Cantrell, L., Schuler, K., Hanna, ... Boggess, J. F. (2017). A comparison of sentinel lymph node biopsy to Iymphadenectomy for endometrial cancer staging (FIRES trial): a multicentre, prospective, cohort study. The Lancet Oncology, 18(3), 384-392. doi.org/10.1016/S1470-2045(17)30068-2.

12. Cusimano, M. C., Vicus, D., Pulman, K., Maganti, M., Bernardini, M. Q. Bouchard-Fortier, G., ... Ferguson, S. E. (2021). Assessment of Sentinel Lymph Node Biopsy vs Lymphadenectomy for Intermediate- And High-Grade Endometrial Cancer Staging. JAMA Surgery, 156(2), 157-164 doi org/10.1001/jamasurg.2020.5060.

13. Schlappe, B. A., Weaver, A. L., Ducie, J. A., Eriksson, A. G. Z., Dowdy, S. C., Cliby, W. A., .... Leitao, M. M. (2018). Multicenter study comparing oncologic outcomes between two nodal assessment methods in patients with deeply invasive endometrioid endometrial carcinoma: A sentinel lymph node algorithm versus a comprehensive pelvic and paraaortic lymphadenectomy. Gynecologic Oncology, 151(2), 235-242. doi.org/10.1016/j.ygyno.2018.08.022.

The lymph node assessment in treatment of endometrial cancer. The state of the problem

O. Bubliieva, V. Svintsitskyi, S. Nespryadko, N. Tsip, V. Kopetskyi, M. Krotevich, N. Leonova, O. Movchan

National Cancer Institute, Kyiv

Summary. Endometrial cancer holds the third place in the structure of malignancies in Ukraine $(9.6 \%)$ among all nosology forms of cancer. Pelvic and para-aortic lymph nodes dissection (LND) belongs to the methods for assessment of lymphatic nodes status. Nevertheless, trials conducted earlier show the absence of LND influence on the survival of patients with EC. Logical alternative might be a sentinel lymph node mapping (SLNM) by use of indocyanine green (ICG) followed by the biopsy which allows evaluating the status of lymphatic nodes with the least resort to radical surgery. Our prospective, randomized, noninferiority study is multi-center clinical trial goaled at comparing the PFS in women with EC from the intermediate as well as highintermediate risk groups, who had been performed SLN biopsy and systemic lymphadenectomy (pelvic and para-aortic lymph nodes dissection).

Key words: uterine cancer; lymph node dissection; sentinel lymph node; indocyanine green.

Aдреса:

Бублісва Ольга Іванівна

03022, Київ, вул. Ломоносова, 33/43

Національний інститут раку

E-mail: bublieva93@ukr.net

Correspondence: Bubliieva Olga

33/43 Lomonosova str., Kyiv 03022

National Cancer Institute

E-mail:bublieva93@ukr.net 